\title{
Need Analysis of M-Learning for Basketball Class
}

\author{
Febrita Paulina Heynoek \\ Sport Scinece Faculty \\ Universitas Negeri Malang \\ Malang, Indonesia \\ febrita.paulina.fik@um.ac.id \\ Prisca Widiati \\ Sport Scinece Faculty \\ Universitas Negeri Malang \\ Malang, Indonesia \\ prisca.widiati.fik@um.ac.id
}

\author{
Ari Wibowo Kurniawan \\ Sport Scinece Faculty \\ Universitas Negeri Malang \\ Malang, Indonesia \\ ari.wibowo.fik@um.ac.id
}

\author{
Rama Kurniawan \\ Sport Scinece Faculty \\ Universitas Negeri Malang \\ Malang, Indonesia \\ rama.kurniawan.fik@um.ac.id
}

\begin{abstract}
This study aims to develop BL-based learning applications using a mobile application, produce learning models with the aim of improving student performance in practical lecture learning, examine the learning model process for wider use. Development, Implementation, Evaluation (ADDIE). The results show that $69 \%$ of students have never used M-Learning for basketball courses. A total of $93 \%$ of students think that it is necessary to develop new media that can increase the effectiveness and efficiency of learning. $72 \%$ of students hope that the developed media can be accessed via smartphones and laptops, light capacity, contains text, images, audio, visual, and audio-visual. $64 \%$ of students agree that this media can be used and is very effective and efficient in learning
\end{abstract}

Keywords-blended learning $(B L)$, m-learning, mobile application, bolabasket.

\section{INTRODUCTION}

The years 2020-2021 are quite a tough period for education in Indonesia, where teaching which is usually carried out in one direction requires students to meet face-to-face with teachers. The existence of a pandemic that limits the mobility of students also requires teachers to reform the system and teaching methods, especially in practical lectures. The method using blended learning (BL) provides a solution to this problem, with related research results, such as the level of student understanding, because the pace of learning is carried out individually. Supports the development of lifelong learning by providing a student-centred environment. The flexibility of the mixed environment provides a rich educational experience for students with an active learning emphasis. The University values and strives to instill skills essential for lifelong learning, producing graduates who continue to develop intellectually, professionally and socially beyond the confines of formal education.[1][2][3]

Some of the obstacles that will be faced when conducting BL while in the field are that this method requires high-quality support at all levels: organizational infrastructure, course and faculty development, and consistent student learning support mechanisms. All elements must play a role in a responsive and reliable institutional culture. Obviously, these elements require an adequate investment of resources. However, with this investment comes the need for an effective evaluation process, which provides information that facilitates effective decision making at both the policy and instructional levels.[4][5]

Many previous studies have developed applications and methods in developing BL learning methods, one of which is developing the web as a development model [6][7][8][9][10], many of which have developed based on M-Learning[11][ 12], but no one has included podcasts and presences in the BL development model, especially in Indonesia. The research that will be carried out will update the features to make it easier for teachers and students to carry out the learning process, the objective elements in the assessment will be clearly visible later.

The majority of learning in 2021 will be conducted with BL, with a composition of $25 \%$ face-to-face and $75 \%$ asynchronous and synchronous. With the initial data that bridges the needs of students and also evaluates the teachers, this method will be effective, especially in FIK UM later. Product specifications are in the form of a mobile application which supports independent learning, with learning materials 
provided, illustrated e-books accompanied by barcodes that connect to video link examples of movements, pretest, post-test, attendance, podcasts from several experts in the field of basketball ( national coaches, event management, professional players) support the concept of independent learning, UTS, and UAS. The product will be tested in small groups, then it will be used in all 8 classes of basketball courses at FIK UM. If the product has been standardized nationally, this product can be used by teachers throughout Indonesia who teach basketball courses, especially universities that have a Faculty of Sports Science. Learning that is easily accessible and has complete features, such as a speech from the Minister of Education and Culture, Nadiem Makarim, stated that online learning will become permanent in Indonesia at universities.

The aims of this study are: (a) developing BL-based learning applications using a mobile application, (b) producing learning models with the aim of improving student performance in practical lecture learning c) reviewing the learning model process for wider use.

Technological innovation affects the learning process in an area or country, expanding the range of possible solutions that can be given to various problems. BL is a technology-based innovation that combines the composition of face-to-face meetings between students and teachers, online, and offline.[13] Face-to-face students are required to be present at the venue and carry out a traditional learning system, by making the teacher the center of point. Online learning has the advantage of being flexible in time and place by students and teaching, but there are several obstacles if the system or infrastructure is inadequate and cannot learn optimally. Offline learning can be packaged in many forms and is not connected to the network, making it easier for students and teachers to access the material, but the costs incurred are also quite high for this method.[14] The challenge now is to make learning experiences more effective, increase access and flexibility, or reduce learning costs, it is likely that BL learning systems will provide a mix of face-to-face and computer-mediated experiences. Future learning systems will not be differentiated based on whether they blend in or how they blend in. Like any design problem, this challenge is highly context dependent with practically unlimited possible solutions.[3][15][16]

\section{A. Mobile Learning}

Looking at the state of mobile learning around the world, several critical issues can be highlighted. The current section aims to highlight similar issues, concerns and mindsets in the seven regions reviewed in Canada, the US, Europe, Russia and Ukraine, Latin America, Africa, and the Middle East, Asia and the
Pacific.[17] The rapid development of mobile devices (including smartphones) is a commonly observed phenomenon. Recent studies estimate that access to mobile devices is far superior to access to laptops or PCs (personal computers) due to the low cost of mobile phones. [18] Despite the challenging new environment for mobile learning to immerse itself in around the world, supported also by the expansion of $3 \mathrm{G}$ or $4 \mathrm{G}$, technology adoption rates for mobile learning are not developing at the same rate.

Potential positive effect for the disability of students and children with special needs learning to communicate and interact with others using mobile devices.[19] Though, accessibility issues also arise for many mobile devices because they can't be used by people of different ages and different problems. The lack of educational policies that specifically address the issue of mobile learning leads to another side effect that also appears to be a significant roadblock to the adoption of mobile learning.

The problems that are often faced in the use of MLearning are:

1. Disruption of students in the classroom, safety concerns, exposure of students to risky environments containing inappropriate material, hostile behavior such as cyber bullying, sexual misconduct or sexting, potential for cheating during school exams and game addiction.

2. Negative effects on students' health and their physical development, further reinforcing the ambiguity of key role players (ie, in the Asian region) regarding the appropriateness of mobile device use in schools.

3. The most frequently reported negative implications, thermal and non-thermal effects, radiation absorption cause cancer, asthenopia, excessive eye strain resulting from excessive cell phone use, etc. [17]

To overcome the problems above, so the learning strategy must pay attention to several things, namely:

- fair use;

- flexible use

- simple and intuitive

- visible information;

- tolerance for faults;

- low physical and technical effort;

- student community and support; and

- learning climate.

Learning using M-Learning has the potential to transform learning spaces and transcend the boundaries of traditional physical and conceptual education.[20] Mobile learners can traverse different learning spaces to build and build with them learning experiences Five conceptual spaces of mobile learning were identified as essential elements of the m-learning ecosystem. While some of the characteristics of those spaces are illustrated, the emphasis of the discussion 
remains on their interactions and the opportunities presented by the overlap and interrelationships of these fields. The next topography of mobile learning includes the following spaces: (1) temporal, (2) physical, (3) transactional: intrapersonal, personal, and interpersonal (social and public), (4) technology, and (5) pedagogy.[21].

\section{METHOD}

1. Desain penelitian

This study uses the Research and Development $(\mathrm{R}$ and $\mathrm{D})$ model of Analysis, Design, Development, Implementation, Evaluation (ADDIE). The research design is divided into 3 parts, namely planning research design, product manufacturing, and the implications of BL-based m-learning.

2. Research place and time

Research This research was conducted at FIK UM. This research is planned to take place from March to November 2021.

3. Research Instrument Data Collection Techniques

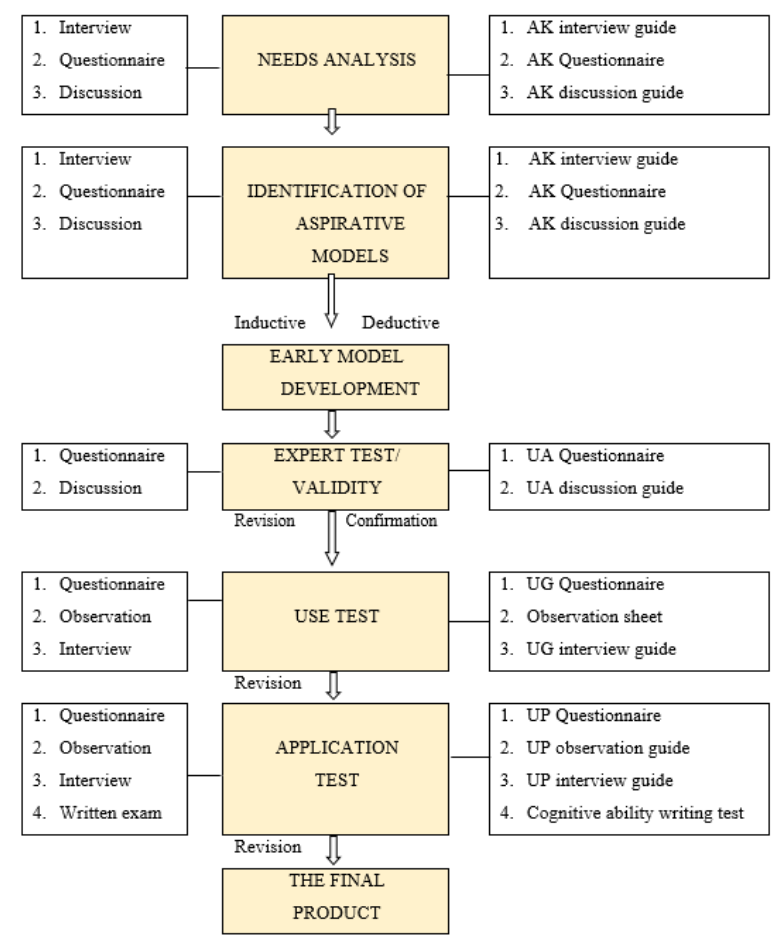

Fig. 1 R\&D Pattern

\section{Data Analysis Techniques}

To analyze the quantitative data used descriptive statistics, namely percentage and mean analysis.

4. Research design

The procedure used in this study consists of seven steps, namely: (1) conducting a needs analysis, (2) identifying an application model that suits the needs of students, (3) developing a model, (4) conducting expert tests, (5) conducting tests small-scale trial (test using the model), (6) conduct a field test (test the application of the model) using action research (action research), and (7) produce the final model

\section{B. $\quad$ Karakteristik subjek}

The research subjects were students of class 2019 study program PJK, PKO, IKA, Faculty of Sports Science, State University of Malang. The number of students who filled out the online questionnaire was 72 people. There were 72 research subjects (students) in this study whose data collection instrument was an online questionnaire to collect information about the understanding of FIK UM students about basketball lectures. The results of data collection will be described in accordance with the questions asked in the online questionnaire. The results can be described as follows:

\section{a. $\quad$ Students Taking Basketball Courses \\ Percentage Who Have Taken Basketball Course

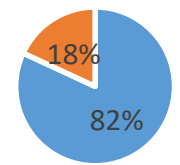 \\ - Ever been " Never \\ Fig. 2. Percentage Who Have Taken Basketball Course}

Of the 72 research subjects: 59 research subjects had received and underwent basketball courses; 13 research subjects have not received and undergo basketball courses). These data indicate that the subject of this research is not all students who are the subject of the study have received basketball courses.

b. Acquisition of Basic Basketball Technique Material

Percentage of Students Who Have Received Basic Basketball Techniques

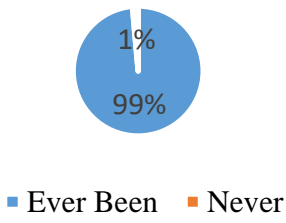

Fig. 3 Percentage of Students Who Have Received Basic Basketball Techniques

The data in the results section shows the acquisition of basic basketball technical material for 2019 students. 
The data shows that a total of 71 students have received basic basketball technical material and the rest have not.

\section{c. Basketball Invasion Game Material Acquire}

Percentage of Students Who Have Received Basketball Invasion Game Materials

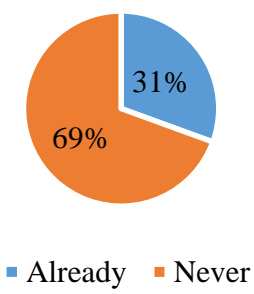

Fig. 4 Percentage of Students Who Have Received Basketball Invasion Game Materials

The data in the results section shows the acquisition of material for the 2019 student basketball invasion game. The data shows that a total of 22 students have received basic basketball technical material and 50 have not.

\section{d. Acquisition of Basketball Refereeing Material \\ Percentage of Students Who Have Received Basketball Invasion Game Materials

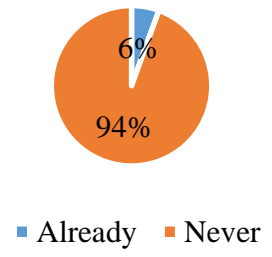

Fig.5 Percentage of Students Who Have Received Basketball Invasion Game Materials

The data in the results section shows the acquisition of material for the 2019 student basketball invasion game. The data shows that a total of 4 students have received basic basketball technical material and 68 people have not.

e. Data analysis

The data analysis technique is used to analyze quantitative data using descriptive statistics, namely percentage and average analysis.

\section{RESULT AND DISCUSSION}

Data pada bagian hasil menunjukkan bahwa 59 subjek penelitian telah menempuh mata kuliah bola basket sedangkan 13 subjek penelitian belum menempuh mata kuliah bola basket.

\section{A. Frekuensi Mahasiswa dalam Penggunaan media m-learning yang berisi materi perkuliahan bolabasket}

Frequency of Students in Using m-learning media containing basketball lecture material

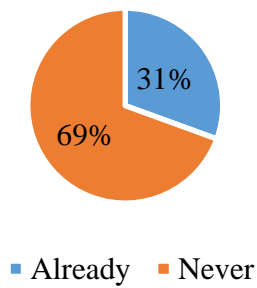

Fig. 6 Frequency of Students in Using m-learning media containing basketball lecture material

The data in the results section shows that 59 research subjects have taken basketball courses while 13 research subjects have not taken basketball courses.

\section{B. Student Opinions in Using Application Media That Contains Basic Basketball Techniques}

Percentage of Student Disapproval of the Effectiveness and Efficiency of Application Media That Contains Basic Basketball Techniques

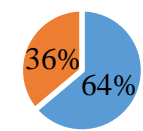

- Agree - No

Fig.7 Percentage of Student Disapproval of the Effectiveness and Efficiency of Application Media That Contains Basic Basketball Techniques

The data in the results section shows that 46 students agree that the M-Learning application media is very effective and efficient for basketball learning. 
C. The Importance of Developing New Media in Basketball Lectures

There is a need for the development of new media in basketball lectures so that the learning process becomes more interesting

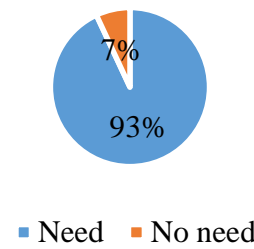

Fig. 8 development of new media in basketball lectures so that the learning process becomes more interesting

The data in the results section shows that 67 students need the development of new media in basketball lectures so that the learning process becomes more interesting.

\section{Expected Media to Increase Knowledge about Basketball}

\section{Media That Students Expect To Develop}

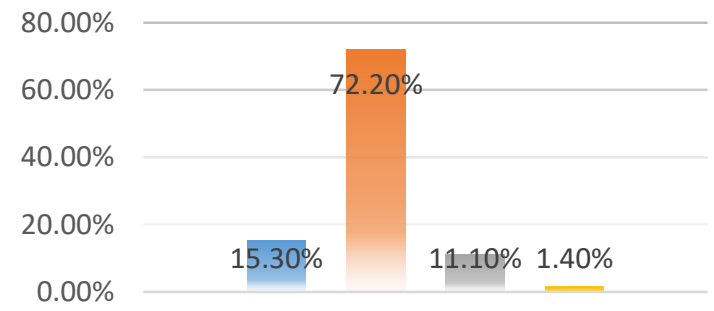

- Contains text, images, audio, visual, audio-visual

Can be accessed via smartphone or laptop, Light capacity,

Contains text, images, audio, visual, audio-visual

- Light capacity, Contains text, images, audio, visual,

audio-visual

M-Learning

Fig. 9 Media That Students Expect To Develop

- Contains text, images, audio, visual, audio-visual= 11 People

- Can be accessed via smartphone or laptop, Light capacity, Contains text, images, audio, visual, audiovisual $=52$ People

- Light capacity, Contains text, images, audio, visual, audio-visual $=8$ people
- M-Learning = 1 Person

The data in the results section shows that the opinion of the research subjects hopes that the developed media can be accessed through anything, by anyone and anywhere as needed. That way the product developed can be useful.

\section{E. Expected Display Wishes In The Application}

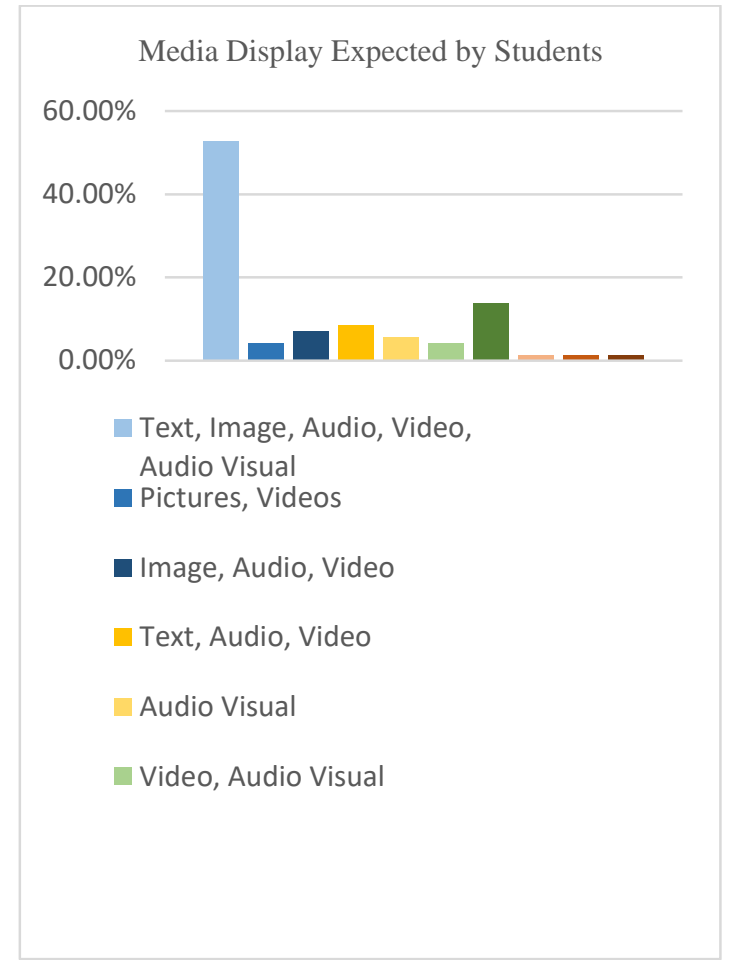

Fig. 10 Media Display Expected by Students

The data in the results section shows that the content of the developed media must be easy for users to understand. Besides being seen, the media can also be felt. Through the senses of hearing, sight and others. It is intended that the products developed can be actualized as best as possible.

\section{F. Material Variations in Media}

From the bar chart above, students expect that the material in the media is presented thoroughly. including basketball history and equipment, basic basketball techniques, combination of basic basketball techniques, invasion games or modifications to basketball games, refereeing and organizing basketball matches. With the hope that students can understand and apply all the material listed. 


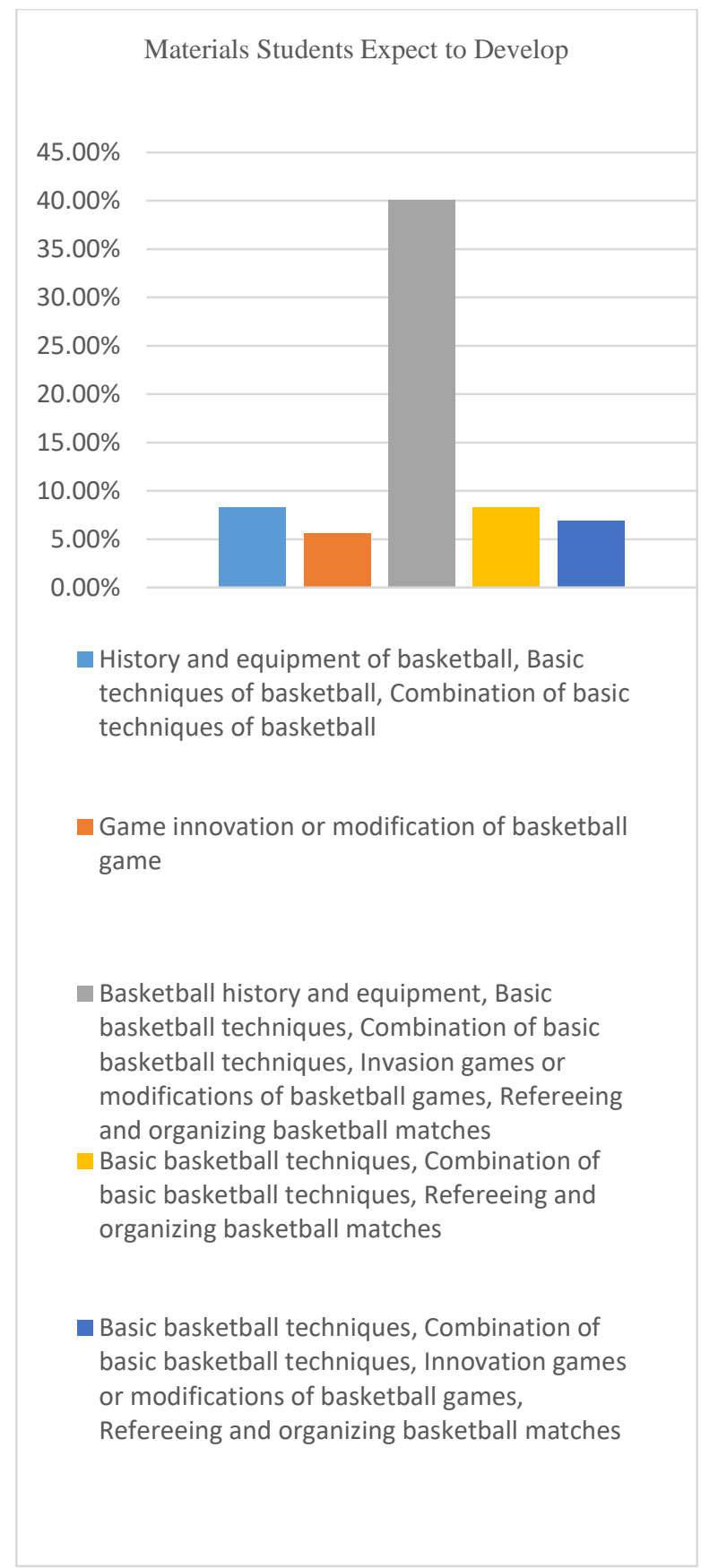

Fig. 11. Materials Students Expect to Develop

\section{CONCLUSION}

To update the features using blended learning (BL) to make it easier for teachers and students to carry out the learning process, the objective element in the assessment will be clearly visible later. In addition, this study aims to develop BL-based learning applications using a mobile application, produce learning models with the aim of improving student performance in practical lecture learning, reviewing the process of learning models for wider use.
Based on the results, $69 \%$ of students have never used M-Learning for basketball courses. A total of $93 \%$ of students think that it is necessary to develop new media that can increase the effectiveness and efficiency of learning. $72 \%$ of students hope that the developed media can be accessed via smartphones and laptops, light capacity, contains text, images, audio, visual, and audio-visual. Students hope that this development can make it easier and present material that is more varied and not boring.

\section{REFERENCES}

[1] P. D. Candidate and M. Giannousi, "A COMPARISON OF STUDENT KNOWLEDGE BETWEEN TRADITIONAL AND BLENDED INSTRUCTION IN A," no. January, pp. 99-113, 2014.

[2] N. Vernadakis, M. Giannousi, V. Derri, and M. Michalopoulos, "The impact of blended and traditional instruction in students , performance," vol. 1, pp. 439-443, 2012, doi: 10.1016/j.protcy.2012.02.098.

[3] S. Shi, Z. Abidin, and B. Zainuddin, "A REVIEW OF THE RESEARCH ON BLENDED LEARNING IN PHYSICAL EDUCATION IN CHINA AND INTERNATIONAL Trends in the Number of Literature," vol. 7, no. 11, pp. 672-686, 2020.

[4] P. Moskal, C. Dziuban, and J. Hartman, "Internet and Higher Education Blended learning : A dangerous idea ?," Internet High. Educ., vol. 18, pp. 15-23, 2013, doi: 10.1016/j.iheduc.2012.12.001.

[5] L. C. Medina, "Blended learning : Deficits and prospects in higher education," vol. 34, no. 1, pp. 42-56, 2018.

[6] S. M. Aslani and H. H. Tabrizi, "Teaching Grammar to Iranian EFL Learners through Blended Learning Using Multimedia Softwares," vol. 2, no. 8, pp. 76-87, 2015.

[7] R. Shih, "Blended learning using video-based blogs : Public speaking for English as a second 
language students," vol. 26, no. 6, pp. 883897, 2010.

[8] T. W. Jing, S. Lim, P. Voon, and S. D. Nagappan, "Learning Environment via Learning Management System , Social Learning Platform and Video: A Case Study at Taylor's," pp. 323-329, doi: 10.1007/978981-287-399-6.

[9] I. W. E. Mahendra et al., "Design of Digital Test Using Wondershare in Supporting the Blended Learning with Kelase Platform," vol. 8, no. 3, pp. 953-959, 2020, doi: 10.13189/ujer.2020.080330.

[10] J. C. Evans et al., "Blended learning in higher education: professional development in a Hong Kong university," High. Educ. Res. Dev., vol. 0, no. 4, pp. 1-14, 2019, doi: 10.1080/07294360.2019.1685943.

[11] Y. Wang, G. Sun, and H. Shi, Research on Blended Learning Activity and Application, vol. 1. Springer International Publishing.

[12] M. C. Borba, P. Askar, J. Engelbrecht, G. Gadanidis, S. Llinares, and M. Sánchez, "Blended learning, e - learning and mobile learning in mathematics education," $Z D M$, 2016, doi: 10.1007/s11858-016-0798-4.

[13] A. Bryan, K. N. Volchenkova, and R. Federation, "BLENDED LEARNING : DEFINITION , MODELS , IMPLICATIONS FOR HIGHER EDUCATION," vol. 8, no. 2, pp. 24-30, 2016, doi: 10.14529/ped160204.

[14] S. Hrastinski, "What Do We Mean by Blended Learning ?,” pp. 564-569, 2019.

[15] B. Learning, "Evolution of Blended Learning," pp. 1-21, 2018.

[16] A. Bliuc, P. Goodyear, and R. A. Ellis, "Research focus and methodological choices in studies into students , experiences of blended learning in higher education," vol. 10, pp. 231-244, 2007, doi: 10.1016/j.iheduc.2007.08.001.

[17] P. A. Publishing, "Research and Reflection in Educational Sciences ( EJRRES ),” vol. 7, no. $12,2019$.

[18] A. Tsinakos and M. Ally, Global Mobile Learning Implementations and Trends. .

[19] L. Petrakieva, "Mobile Technologies and Learning: Expectations, Myths, and Reality 2 Myths and Expectations," pp. 1-8, 2015, doi: 10.1007/978-3-642-41981-2.

[20] T. Elias, "Moodle," vol. 11, no. 2, 2010.

[21] J. Keengwe and M. Bhargava, "Mobile learning and integration of mobile technologies in education," 2013, doi: 10.1007/s10639-013-9250-3. 